\title{
La prensa satírica bogotana en contexto sudamericano a finales del siglo XIX*
}

\author{
Silvina Sosa Vota \\ Universidad de Santiago de Chile, Santiago, Chile \\ silvina.sosa.vota@gmail.com \\ https://orcid.org/0000-0003-3962-1595
}

\section{RESUIMEN}

El artículo tiene como objetivo prin- cularidades que se destacan en este país. cipal reflexionar sobre la prensa satírica Asimismo, se busca esbozar las potenciacolombiana del siglo XIX en el contexto de lidades que este tipo de periódicos tienen Sudamérica. Para ello, es necesario realizar, como fuente de la construcción del conocien primer lugar, un panorama general de las características de este tipo de publicaciones en la región. Posteriormente se introduce el caso de Colombia para observar las partimiento histórico, para lo cual es necesario vincularlo con su contexto de producción.

Palabras clave: caricatura; Colombia; siglo XIX, prensa satírica, Sudamérica.

Cómo citar: Sosa Vota, S. (2020). La prensa satírica bogotana en contexto sudamericano a finales del siglo XIX. Ciencias Sociales y Educación, 9(18), 23-55. https://doi.org/10.22395/csye.v9n18a2

Recibido: 29 de mayo de 2020.

Aprobado: 31 de julio de 2020. 


\section{The Satirical Press from Bogota in the South-American Context of the Late XIXth century"}

\section{ABSTRACT}

This article's main goal is reflecting upon the Colombian satirical press of the XIXth century in the South-American context. For that, a general panoramic of the characteristics of this type of publication in the region was performed. Afterwards, the Colombian case is introduced for observing highlighted particularities in this country.
Likewise, this articles aims towards making evident the potential these type of publication have as a source oh historical knowledge, for which a link with its historical context is necessary.

Keywords: cartoons; Colombia; XIXth century, satirical press, South-America.

\section{A imprensa satírica de Bogotá em um contexto sul- americano do final do século XIX}

\section{RESUMO}

O principal objetivo deste artigo é refletir sobre a imprensa satírica colombiana do século XIX no contexto sul-americano. Por isso, primeiramente, é necessário construir um panorama geral das características desse tipo de publicação na região. Posteriormente, apresenta-se o caso colombiano e observa-se as particularidades que se destacam no país. As potencialidades que esse tipo de jornal tem como fonte de construção do conhecimento histórico, que precisa sempre ser vinculado ao seu contexto de produção, são destacadas.

Palavras-chave: América do Sul; caricatura; Colômbia; imprensa satírica; século XIX. 


\section{Introducción}

A comienzos del siglo XIX, América Latina se vio convulsionada por el surgimiento de inéditas formas de gobierno. Los nuevos Estados nacionales republicanos ${ }^{1}$ que se formaron luego de los procesos independentistas, emprenden un proceso de construcción de sí mismos a nivel político, económico, de infraestructuras y también simbólico y cultural.

En los primeros pasos como Estados independientes, las publicaciones periódicas que antes se encontraban bajo la dirección y control de diferentes agentes vinculados a la monarquía española, comienzan a producirse localmente. Como menciona Bernardo Vasco (2011), en este período se instalan y crecen rápidamente las imprentas en Hispanoamérica, lo que convierte sus publicaciones en importantes plataformas políticas de los criollos independentistas. De esta manera, la prensa contribuye con la consolidación de un sentimiento antiespañol al publicar contenidos vinculados a la nueva coyuntura y sus protagonistas que buscan diferenciarse y romper con el pasado colonial.

Como se desprende de lo anterior, la prensa ha tenido un papel importante en la conformación de comunidades nacionales (Anderson, 1993) y se ha vinculado fuertemente a los procesos políticos. Durante la mayor parte del siglo XIX, las publicaciones periódicas sirvieron de plataforma para que las diferentes facciones políticas expusieran sus reflexiones y debates de cómo deberían pensarse los Estados. De esta manera, respondieron a intereses ideológicos y de facciones en disputa ${ }^{2}$.

Alrededor de la década de 1830, los periódicos comenzaron a sufrir significativas modificaciones gracias a las nuevas tecnologías disponibles. La investigadora argentina Sandra Szir (2017) destaca el resultado del proceso del desenvolvimiento técnico que favoreció el desarrollo periodístico:

Una de las transformaciones más importantes experimentadas por la cultura impresa en el siglo XIX fue el surgimiento y la vasta expansión de la prensa periódica por distintos centros urbanos del mundo [...]. Este impulso [...] sumado a las innovaciones tecnológicas de la multiplicación de imágenes en el campo de la industria tipográfica, habilitó la aparición de un nuevo género, el periódico ilustrado.

Una de las innovaciones a las que hace referencia es la litografía, la cual se desarrolla a comienzos del siglo XIX en Europa occidental de la mano de Aloys Senefelder (1771-1834). Esta técnica de reproducción de imágenes permitió

Con excepción de Brasil, que luego de su "independencia" en 1822 se constituyó como monarquía.

2 Esto se trasformó a finales del siglo XIX con la modernización de la prensa y la profesionalización del periodista. Para el caso chileno, puede leerse una interesante evaluación de esta transformación en el libro Ciudad de voces impresas de Tomás Cornejo (2019). 
lograr este cometido con una velocidad hasta entonces sin precedentes y a bajos costos. Esta técnica

basa su procedimiento en el empleo de materiales grasos como jabón y sebo. Dibujando con dichos materiales sobre la piedra, una vez humedecida, la tinta repartida sobre ella es repelida por la humedad, pero es retenida por los materiales grasos con los que se trazó el dibujo, procedimiento denominado adsorción. Colocando en la prensa la piedra entintada y sobre ella una hoja, se obtiene una o una serie de láminas impresas. (Beretta García, 2012, p. 17)

Con este impulso, las imágenes circulan por los espacios con mayor fluidez que en otros momentos y en una multiplicidad de soportes, tales como libros, folletos, estampas y periódicos. Este último tipo - publicaciones periódicas cuya expansión de títulos venía en aumento- posibilitó, al incorporar la litografía, el surgimiento y popularización de los periódicos ilustrados, lo que permitió que, de alguna manera, la imagen acompañara la cotidianeidad de las personas (Matallana, 2010).

Anterior a la litografía, existía el xilograbado, técnica que utilizaba planchas de madera para la impresión tipográfica y de imágenes. Ambas formas coexistieron durante el siglo XIX, pero la reproducción xilográfica tenía ciertas desventajas en comparación con la litografía. Al ser el tallado de la matriz en madera, los rasgos del dibujo solían ser más toscos, lo que no permitía la inclusión de tantos detalles como en los hechos a través de una piedra litográfica. Por este mismo motivo, la madera se desgastaba más rápido que la piedra y mostraba un progresivo deterioro en el proceso de grabado, para el cual se utilizaba una misma plancha.

En Sudamérica específicamente, estas tecnologías que permitían innovadoras materialidades visuales y comunicativas llegaron con fuerza algunos lustros antes de la mitad del siglo XIX (Rojas Mix, 2009). El uso cada vez más frecuente de la litografía y el xilograbado, permitió la circulación de publicaciones denominadas en su conjunto como prensa ilustrada, expresión que designó a múltiples tipos de periódicos que tenían como eje lo visual, pero que cada cual, a su manera, hicieron diferentes usos de ello. Algunos títulos usaban las imágenes para reforzar una misión educativa, otros querían exaltar en los lectores un sentimiento patriótico a través de la publicación de retratos de "héroes". También habían publicaciones que explotaban una dimensión visual de la sátira política publicando caricaturas en todos sus números. La gran popularización de las publicaciones en la época puede ser entendida como un indicio creciente del placer de las personas en la apropiación y consumo de imágenes (Román, 2010; Szir, 2009). 
Esta transformación en las formas de producir impresos con textos e imágenes se desarrolla en el contexto apuntado con anterioridad: la construcción de los Estados nacionales en América Latina. La prensa satírica, específicamente, se vincula con este proceso porque hacia la segunda mitad del siglo XIX puso en circulación una multiplicidad de imágenes sobre los sujetos, paisajes y costumbres de los contextos nacionales en formación en los que estaba inserta, en una época en la cual la posesión material de una imagen no tenía la cotidianeidad que tiene en la contemporaneidad.

Estos artefactos visuales interpelaron, con los recursos que posee la caricatura —o "arsenal del caricaturista" a decir de Gombrich (1998)—, la coyuntura política del momento; apelaron a la sátira y al humor como formas de vehicular posturas críticas. La investigadora mexicana Fausta Gantús (2012) sostiene que "la caricatura es una forma satírica simbólica de interpretación y construcción de la realidad, una estrategia de acción - de personas y grupos-en las luchas por la producción y el control de imaginarios colectivos" (p. 74). Por este motivo, la inclusión de este tipo de configuración visual en la prensa tuvo una connotación especial en espacios donde se estaban realizando grandes esfuerzos por consolidar un imaginario o una idea de lo nacional vinculada a los recientes e inestables Estados sudamericanos que se encontraban en proceso de definición.

Por esto, Darío Acevedo Carmona hace un llamado a la lectura de estas caricaturas como integrantes del juego político. Estas van interpretando los acontecimientos de la época desde un particular lenguaje plasmado en las páginas de los periódicos que se dirige a un público en particular, capaz de decodificar las imágenes. En este sentido, señala:

la caricatura política representa figuras reconocidas o genéricas (como un partido, una nación, el pueblo, etc.), se basa en situaciones o hechos reales [...] o trabaja con frases o parlamentos dichos por alguna autoridad, lo cual indica que el caricaturista se preocupa por darle identidad a sus creaciones, que está interesado en que se reconozca quién(es) y que situaciones ha dibujado, todo ello con el ingrediente de la ironía y el sarcasmo. (Acevedo, 2003, p. 156)

La historia, de forma general, no se ha ocupado profundamente de las caricaturas presentes en la prensa satírica como fuentes de estudio (Román, 2010, p. 11). Sin embargo, estos periódicos, las imágenes y textos por ellos vehiculadas son importantísimas fuentes para el estudio de los procesos sociopolíticos y culturales del pasado, ya que permiten una aproximación a las representaciones de los distintos sucesos hechas por los propios contemporáneos de los mismos.

Por las características propias de la caricatura, estas particulares formas de configuración visual posibilitan adentrarse a un imaginario político que sintetiza posicionamientos apelando al humor, al afecto, a la empatía o a la repulsión. 
Ernst Gombrich (1998) señala que el estudio de la caricatura también puede mostrar "el papel y la fuerza de la imaginación mitológica en nuestro pensamiento político y sus decisiones" (p. 129). Esto se debe a que, entre otras cosas, evidencian el uso de metáforas, otras figuras del lenguaje y personificaciones para expresar ideas "serias". Desde este punto de vista, es posible y necesario realizar estudios históricos a partir de fuentes visuales que complementen y enriquezcan las tradicionales perspectivas adoptadas desde la historia social y política.

Considerando los aspectos abordados en la introducción, el presente trabajo se propone como objetivo, en primer lugar, reflexionar sobre el género de la prensa satírica en la región sudamericana como un fenómeno decimonónico que fue posible gracias al desarrollo y difusión de nuevas tecnologías, las cuales permitieron cambios sustanciales en las formas de comunicar a través de la prensa. Esbozado este contexto, se buscará trazar un panorama del fenómeno en Bogotá, Colombia, para vislumbrar las particularidades que se destacan en este caso y poder apuntar, a través de ejemplos, las potencialidades del uso de esta fuente para la investigación histórica.

El ejercicio de escalas planteado en el correr de las páginas —de Sudamérica a Bogotá- se propone latinoamericanizar fenómenos compartidos que apenas se analizan en el marco de los Estados nacionales. Se entiende que este ejercicio de contrastes tiene el potencial de permitir destacar las particularidades de cada caso estudiado, así como de evidenciar lo compartido.

\section{La prensa satírica en Sudamérica}

La disponibilidad de nuevas tecnologías en la región sudamericana provocó un cambio cualitativo en las formas de producir impresos de todo tipo que impactó directamente en la cada vez más dinámica circulación de publicaciones. Sandra Szir (2010) vincula estas transformaciones tecnológicas con mudanzas en el área social y las publicaciones en circulación:

A finales del siglo XIX la cultura tipográfica en Buenos Aires manifestó un crecimiento en la producción de objetos impresos ligado a una mutación tecnológica. Esta mutación permitió una disminución de los costos de fabricación y permitió una multiplicación de textos e imágenes a una velocidad y escala desconocidas hasta entonces. Los procesos de industrialización, urbanización, así como la ampliación de la escolaridad que produjo nuevos lectores, una participación política mayor con una masiva demanda de información, y un desarrollo comercial y cultural que incluyó al ocio y al entretenimiento, fueron otros factores que operaron a favor de la circulación de lo escrito de una manera inédita. Esta creciente presencia de material impreso difundido en diversos soportes, tipos y géneros de publicaciones se verificó en distintos ámbitos sociales, educativos, comerciales. Revistas, diarios, libros, fo- 
lletos, estampas, así como trabajos comerciales de todo tipo fueron producidos por un número cada vez mayor de imprentas y establecimientos afines. (p. 23)

Estos cambios acelerados en el plano de las publicaciones ilustradas comenzaron a gestarse poco después del período independentista, con la instalación de las primeras litográficas. Ernesto Beretta García (2012) sostiene que, en el caso uruguayo, esto fue posible gracias a la inmigración de personas provenientes de Europa al libre comercio y progresivo fortalecimiento de lazos con los Estados de dicho continente. Por su parte, la investigadora argentina Mara Burkat (2007) también apunta en la misma dirección y destaca que la expansión de la prensa y el periodismo estuvo fuertemente relacionada con los movimientos migratorios. En este sentido y respecto a los periódicos satíricos, Burkat (2007) señala que la mayoría de los caricaturistas eran españoles e italianos, a los cuales habría que agregar la importante presencia de los franceses.

El género de la prensa satírica en Europa gozaba de gran popularidad con publicaciones como Le Charivari ${ }^{3}$ de París fundada en 1832, el londinense Punch (también llamado London Charivari) inaugurado en 1841 o el madrileño Gil Blas (1864) (González, 2009). Muchos inmigrantes llegados a la región sudamericana arribaban con experiencia acumulada de trabajo en publicaciones de este tipo, bien sea como grabadores, caricaturistas o editores. De esta manera, las producciones locales guardaron estrecho vínculo con sus pares transatlánticos, sobre todo en relación con el formato y a los "arsenales" de los caricaturistas (Szir, 2017).

La presencia de extranjeros puede verse en las capitales de la región al observar las instalaciones de las primeras litografías. En Buenos Aires, este proceso estuvo encabezado por el suizo César Hipólito Bacle en 1828, quien también impulsó la técnica en Santiago de Chile una década después (Szir, 2016). En la capital de la otra orilla del Plata, Montevideo, la litografía llegó junto con el belga José Gielis cerca de 1836 (Beretta, 2012). En Rio de Janeiro, Johann Jacob Steimann, suizo de nacimiento, fue precursor de la técnica y fue litógrafo oficial de la Corte. En Colombia, el ministro plenipotenciario en Francia, Francisco Antonio Zea, obtuvo en París una prensa litográfica para el Gobierno, y contrató a un grabador español, Carlos Casar de Molina, para su puesta en funcionamiento en 1823 (González, 2009).

Los movimientos migratorios, los intercambios, las referencias comunes, entre otros factores, generaron que la prensa satírica en Sudamérica poseyera aspectos similares entre los diferentes títulos que circularon. En primer lugar, pueden apreciarse similares formatos. Algunas publicaciones tenían ocho pá-

En América Latina fueron publicadas revistas con nombres que referían a esta publicación parisina. Por ejemplo, estaba el Charivari Bogotano (1848-1849) y también el santiaguino Charivari (1867-1870). 
ginas, pero una parte significativa de este grupo de periódicos se publica con cuatro páginas, de las cuales dos son de texto y dos son de imágenes, aspecto que apunta hacia la centralidad de lo visual. En ningún caso eran publicaciones voluminosas.

La separación entre páginas con texto exclusivamente y páginas con imágenes se puede explicar - y esta es la segunda característica de similitud- por el uso mayoritario de la litografía. Según Pamela Gionco (2016), "la técnica litográfica remite a un dibujo necesariamente manual, que no puede combinarse con el texto tipográfico, lo que determina una disposición particular de las imágenes" (p. 91). Por esto, las páginas que contienen reproducciones visuales presentan textos escritos a mano en la misma matriz que el dibujo. En el caso de las publicaciones que optaban por la xilografía, esta división entre lo visual y lo textual no era excluyente, y en el caso de estos periódicos se observa la coexistencia de texto y caricaturas en la misma plana (figura 1).

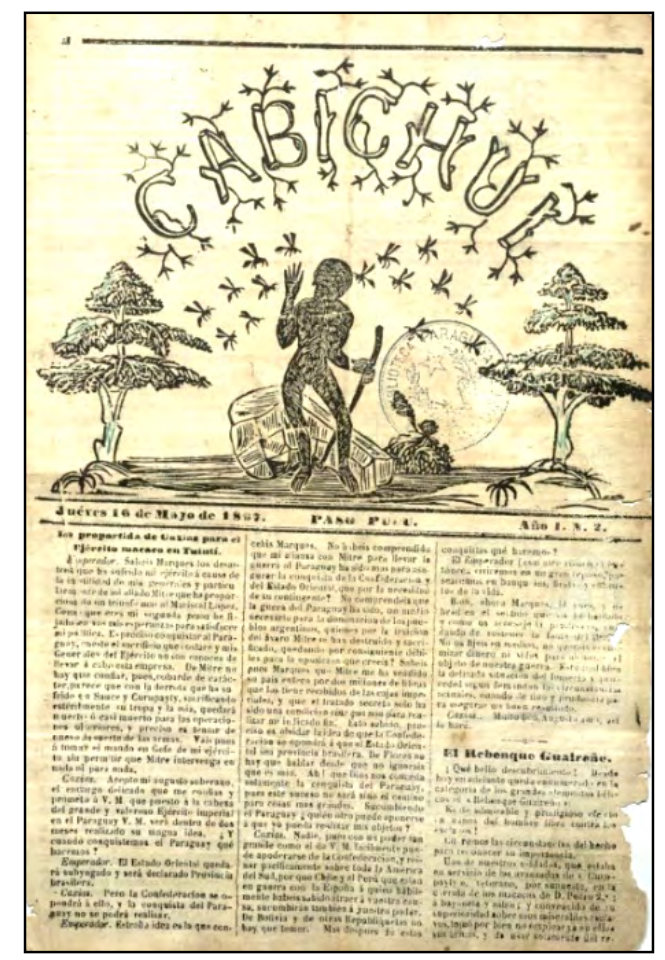

Figura 1. Portada de Cabichuí n. 2

Fuente: Cabichuí (1867).

Por otro lado, usualmente los títulos de los periódicos satíricos hacen referencias a elementos molestos, incisivos o sobrenaturales. En Buenos Aires, 
por ejemplo, se publicó entre 1863 y 1893 El Mosquito, cuyo título refiere a un insecto que zumba y se entromete, al igual que O Mosquito (1869-1877) de Río de Janeiro. En Montevideo, en la década de 1870 circuló La Ortiga y el Garrote, nombre que conjuga la planta que causa alergias y el garrote que golpea. En Santiago de Chile en 1881 apareció El Corvo, palabra que refiere a un cuchillo de forma arqueada. Por último, el periódico de trinchera paraguayo publicado durante la guerra de la Triple Alianza, llevó el nombre de Cabichuí (1867-1868, Paso Pucú), que en guaraní significa avispa.

Estos nombres conducen desde el primer momento a imaginar el carácter de las publicaciones. En algunos casos, los títulos de los periódicos van acompañados de subtítulos que refuerzan aún más esta idea. En el hebdomadario uruguayo se puede encontrar la frase "las ronchas de la ortiga serán curadas por los ungüentos del garrote" (La Ortiga y el Garrote, 1874); en el carioca, "jornal caricato e crítico" (O Mosquito,1869-1877); en el argentino, "periódico satírico i burlesco de caricaturas" (El Mosquito,1863-1893); y por último en el chileno "periódico satírico humorístico de caricaturas" (Cabichuí, 1867-1868). En los últimos se observa un direccionamiento más claro de los objetivos de las publicaciones a la vez que se destaca el eje de las mismas: las caricaturas (figuras 2 y 3 ).

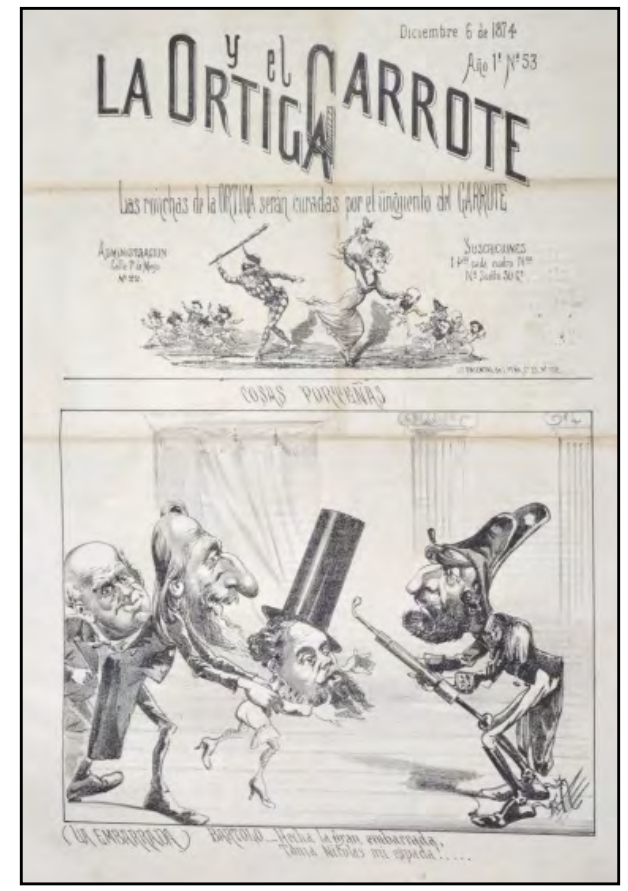

Figura 2. Portada de La Ortiga y el Garrote n. ${ }^{\circ} 53$

Fuente: La Ortiga y el Garrote (1874). 
Las secciones regulares suelen ser muy similares. Un análisis sobre las formas de estructurar el contenido en estos periódicos muestra expresivas semejanzas. En la mayor parte de las publicaciones observadas, en la primera plana se ubica el título (y también subtítulo, si corresponde) de la publicación junto con alguna imagen vinculada a él que se repite número a número. Por otro lado, las partes textuales de la publicación se organizan en tres columnas. Los escritos toman la forma de supuestas cartas de lectores, diálogos entre personajes ficticios ${ }^{4}$ o representaciones de sujetos verdaderos, crónicas, entre otras formas.

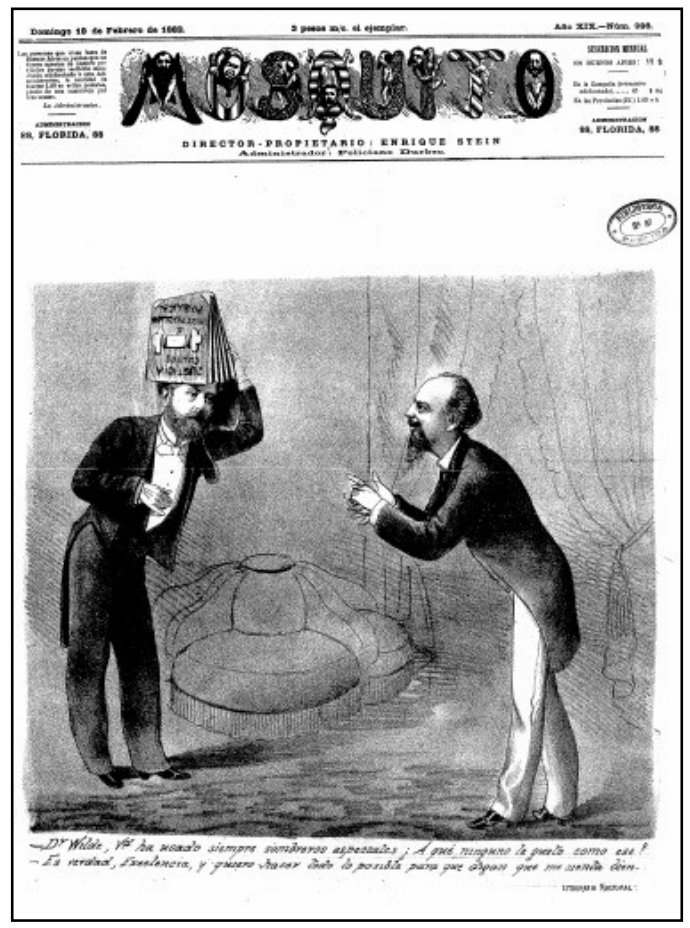

Figura 3. Portada de El Mosquito n. 998

Fuente: El Mosquito (1882).

Al respecto de la similitud entre las secciones, en los periódicos de Montevideo, Buenos Aires y Santiago de Chile es expresiva la presencia de un apartado similar de variable extensión, pero siempre ubicado hacia el final, cuyo título dialoga con el nombre de la publicación: picotones, ortigazos (o garrotazos, dependiendo del número) o cuchilladas (en ocasiones también destripaduras). En esta sección son colocados pequeños textos con contenido de fuerte crítica a la coyuntura particular.

Muchas veces los periódicos satíricos crean un personaje que los representa y participa de las caricaturas. 
Con esto puede vislumbrarse que este tipo de prensa no tenía el propósito de ser imparcial u objetiva, sino que se entendía a sí misma como instrumento de combate. Por ello, tomaron el rol de actores políticos y crearon espacios de disputa en esa arena para constituirse como armas. Los periódicos satíricos recurrieron a lo visual y lo textual para configurar discursos cómicos y mordaces que contribuyeran a la construcción de sentido de la escena política en disputa. Así, se convirtieron en un modo posible de interpelación e interpretación de la misma.

El principal blanco de ataque de las publicaciones son los políticos y el escenario político del momento. Las representaciones predominantes en las caricaturas refieren a los sujetos que protagonizaban el teatro político nacional, quienes eran objeto de burlas y críticas. Pero no solo marcaban distancia con estos, sino que también lo hacían con la denominada "prensa seria". Es posible encontrar múltiples juicios sobre los otros títulos de la prensa nacional con la que convivían, con lo que marcaron así un claro posicionamiento de distancia y búsqueda de diferenciación del género.

Por último, la frecuencia de publicación es similar. La mayoría de los periódicos satíricos son hebdomadarios. Existieron experiencias de publicación de dos veces por semana, pero en la gran mayoría de los casos esta frecuencia no pudo sustentarse en el tiempo, por lo que casi siempre retornaron a la publicación semanal.

De forma general, el género de la prensa satírica se estancó y se agotó hacia finales del siglo XIX y comienzos del siglo XX. En este momento se dieron importantes impulsos modernizadores que modificaron sustancialmente las formas de concebir el periodismo y gestionar una publicación periódica. Más que responder a intereses políticos, ideológicos o partidarios como en las décadas inmediatamente anteriores, las publicaciones periódicas buscaron dirigirse a públicos más amplios, pautadas por una lógica de mercado que adoptó, en el caso de la prensa ilustrada, el formato magazín. Por este motivo, "el humor comenzó a incursionar en temas menos conflictivos y menos politizados" (Levín, 2015, p. 63).

Esta mutación fue posible, además, por la disponibilidad de nuevas tecnologías de reproducción de imágenes que permitieron las publicaciones a color. Nuevas técnicas de composición visual como el fotograbado, por ejemplo, también fueron incorporadas (Costa, 2009; Cuarterolo, 2017). Así, las publicaciones ilustradas cambiaron sustancialmente la calidad del producto final y marcaron el fin del período de la prensa satírica decimonónica 
Sobre el nuevo tipo de ilustraciones humorísticas que se publican al comenzar el siglo XX, Florencia Levín (2015) apunta que "tanto la caricatura como los cartoons o chistes dibujados y la historieta fueron ganando espacio y diversificando sus campos temáticos y estilísticos, superando de este modo la casi exclusiva concentración en la caricatura política de las publicaciones decimonónicas" ( p. 63). Como ejemplo de esto, pueden encontrarse publicaciones del tipo de la bonaerense Caras y Caretas (1989-1941) o la chilena Zig-Zag (1905-1964), que ya desde la configuración de sus portadas y el uso del color se puede observar un salto cualitativo en relación con sus predecesoras (figura 4).

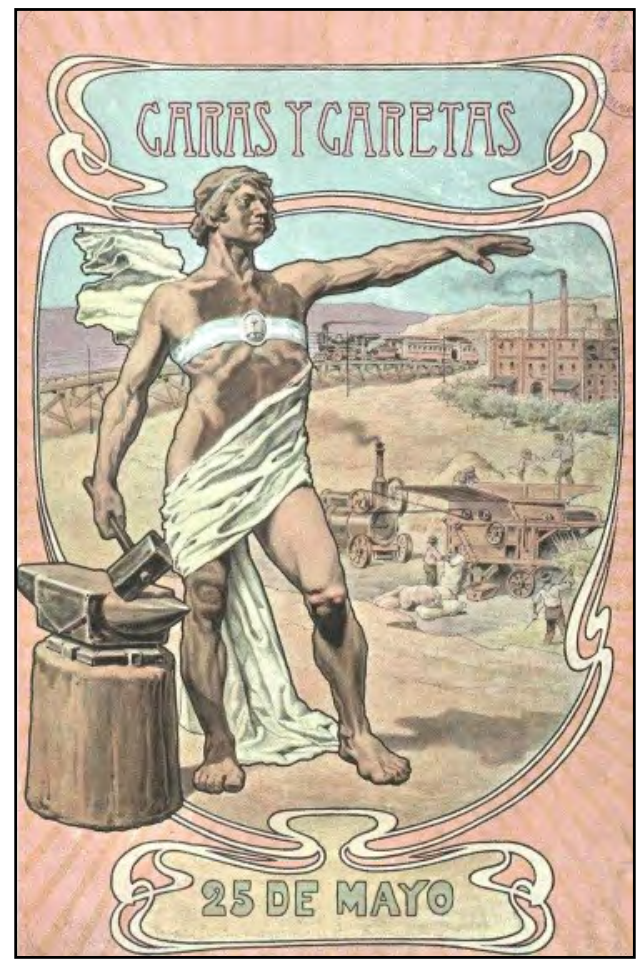

Figura 4. Portada de Caras y Caretas n..$^{\circ} 86$

Fuente: Caras y Caretas (1900).

\section{La prensa satírica en Bogotá}

Al igual que en Argentina, Uruguay, Chile, Brasil y Paraguay, en Colombia también tuvo fuerte impacto la prensa satírica en el siglo XIX. Teniendo en cuenta las reflexiones previas sobre el fenómeno en el espacio sudamericano, en esta sección se revisará la producción del tipo de prensa en cuestión que circuló en la capital colombiana en la segunda mitad del siglo XIX. 
Para pensar la prensa satírica bogotana en particular se han escogido algunos títulos relevantes de finales del siglo XIX que tuvieron gran destaque en su contexto. El primero de ellos es El Zancudo (figura 5). Este periódico fue publicado entre el 22 de marzo de 1890 y el 11 de octubre de 1891, fecha en que fue cerrado por orden del Gobierno. No obstante, en sus páginas se menciona que fue el año 1790 o 1791, y que el lugar de publicación era el Virreinato de Nueva Granada, con lo que refirieron una época y un lugar distintos a los reales. Según Beatriz González (2009), este intencional cambio de fecha tenía la función de generar una perspectiva temporal con respecto al proceso de regeneración y sortear, así, la censura de forma burlona.

Esta actitud irónica también se observa en el subtítulo adoptado: "periódico cándido, antipolítico, de caricaturas, costumbres y avisos" (El Zancudo, 1791). Con estos adjetivos, se refiere a sí mismo como un tanto inocente y contrario a la política. Sin embargo, a lo largo de sus páginas y ediciones demuestra todo lo contrario, pues representaron el mundo del poder desde una perspectiva particular y una cierta astucia propia de la caricatura que, además, es crítica y combativa con sus objetivos.

En la primera plana de la publicación aparecen como responsables de redacción El...oy Rey, de dirección Serafín Boquiflojo, los dibujantes Rump y Raff y los grabadores Riff y Reff. Todos estos pseudónimos probablemente se colocaron con el ánimo de evitar represalias a las personas reales detrás de la publicación.

El periódico se imprimía semanalmente en la imprenta El Progreso, cuyo dueño era el mismo impulsor de la revista: Alfredo Greñas (1857- 1949). También fue fundador de otros periódicos del medio colombiano como El Barbero (1892-1893).

La publicación constaba de cuatro páginas, en las cuales se incluían textos y caricaturas. Al menos una imagen de este tipo contenía cada edición. En ocasiones se observan pequeñas imágenes al comienzo de la columna que introducen el texto. La técnica utilizada era la xilografía.

En el primer número, en su texto de presentación, coloca:

El Zancudo no tiene filiación política pues quiere vivir tranquilo y reírse de unos y otros á zanca tendida; la mayor de las necesidades es calentarse la cabeza con estas cosas del Gobierno [...]. No ofrecemos, como el malogrado Imparcial que vamos a "flagelar sin compasión" á [sic] nadie. Nos reiremos de muchos prógimos [sic], pero nuestros tiros no pasarán de causar una insignificante herida en la epidermis. Hay muchos malos hábitos, muchas malas costumbres y muchas malas prácticas que deben extirparse: queremos ofrecer nuestro risueño contingente en la labor social. (El Zancudo, 1790 [1890], p. 1) 


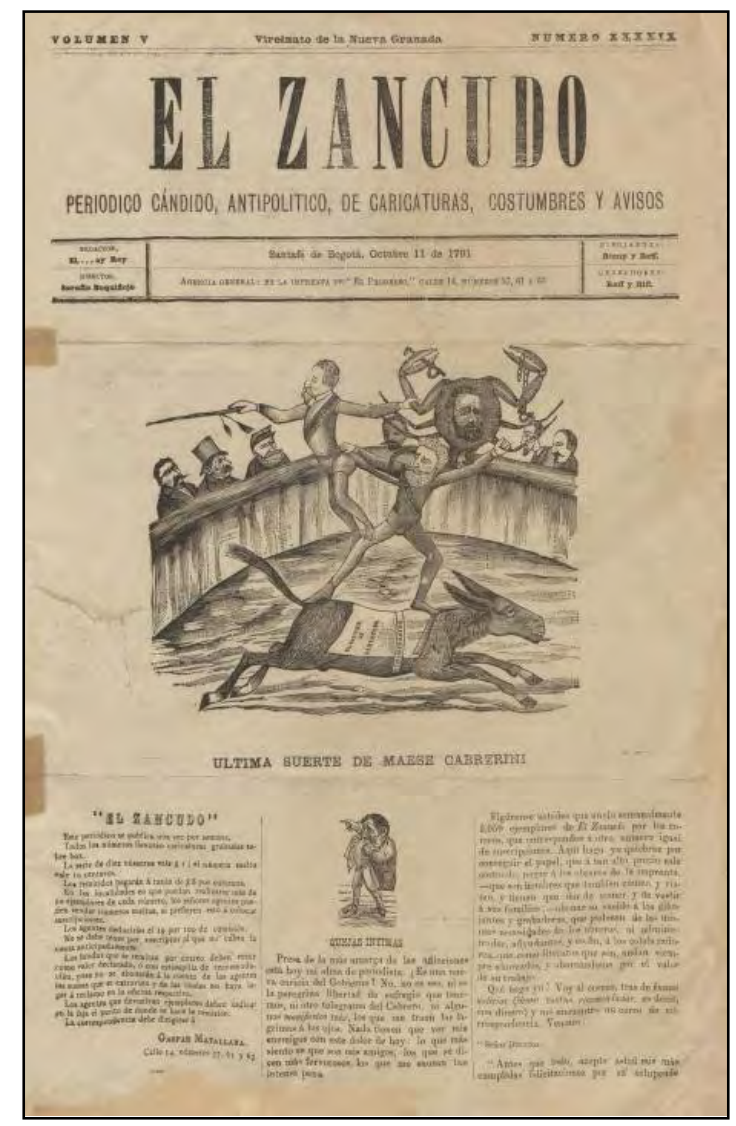

Figura 5. Portada de El Zancudo n. ${ }^{\circ} 49$

Fuente: El Zancudo (1791 [1891] ${ }^{5}$.

Con esto declara que el humor será la principal forma que tomará su discurso con el cual se dirigirá a muchas personalidades del mundo de la política, especialmente a quienes están en el Gobierno. Esto introduce una de las características que Andrea Matallana (2010) observa en el género para el caos argentino, pero que puede ser aplicada también aquí: la caricatura es necesariamente opositora, "sino no se puede lograr el efecto humorístico deseado" ( p. 13).

Por otro lado, se puede apreciar en este breve texto una de las características de este tipo de publicaciones que había sido mencionada anteriormente: además de la crítica al escenario político en el que se desarrollaban, también

$5 \quad$ Al respecto de estas fechas, Gonzáles (2009) informa: "El Zancudo salió a la luz pública el 22 de marzo de 1890 pero fue fechado con un siglo de anterioridad -el 22 de marzo de 1790 en Santafé de Bogotá y el Virreinato de Nueva Granada - no solo para esconder la identidad de los participantes y despistar a la censura sino para divertirse mirando la Regeneración en perspectiva". 
dirigieron fuertes ataques a las otras publicaciones con las que compartían en el espacio de circulación. En este caso, se habla de un periódico "malogrado" que, por coincidir en fechas, probablemente se trate de El Imparcial: periódico político, literario y noticioso de la imprenta de Lleras y Cía.

El Barbero (figura 6), como fue mencionado anteriormente, también fue fundado por Greñas y circuló entre el 27 de marzo de 1892 y 16 de enero de 1893. Según González (2009), este fue el último semanario instituido por este relevante sujeto del escenario periodístico colombiano antes de ser obligado a partir al destierro.

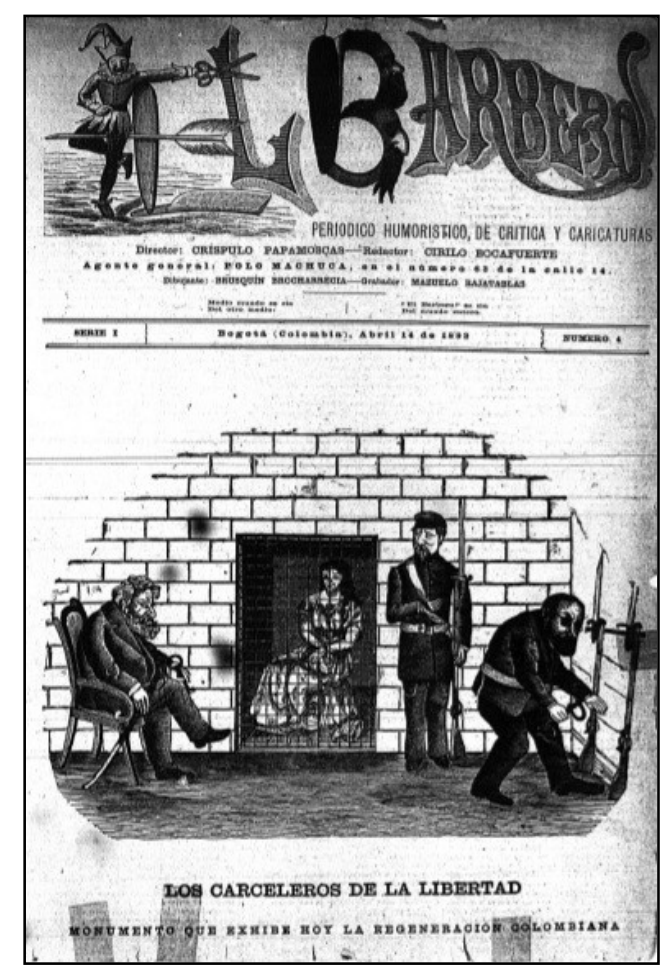

Figura 6. Portada de El Barbero n. ${ }^{\circ} 4$

Fuente: El Barbero (1892b).

Al igual que El Zancudo, El Barbero se imprimía en la imprenta El Progreso y contaba con cuatro páginas que medían cuarenta y cinco por treinta y dos centímetros. Utiliza también el mismo recurso de pseudónimos que su "publicación hermana" pues figura como su director Crispulo Papamoscas, su redactor Cirilo Bocafuerte, como dibujante Brusquín Bocharrecia y como grabador Mozuelo Rajatablas. Tenía un valor de diez centavos. 
Las partes textuales de la publicación se organizaban en tres columnas y, gracias a la utilización del xilograbado, el texto frecuentemente se intercalaba con las imágenes. Al respecto de estas, en las primeras ediciones tienen más centralidad las caricaturas políticas, pero a medida que van avanzando los números las escenas costumbristas cobran mayor protagonismo. Esto último se explica por la fuerza de la censura en esta época, tema que se tratará más adelante.

El lema de la publicación era: "Medio mundo se ríe, del otro medio. El Barbero se ríe, del mundo entero" (El Barbero, 1892b). De esta manera, identificaron un escenario de disputa de dos bandos en el que la publicación se ubica por encima sin identificación con uno u otro. En su texto de presentación coloca:

Henos aquí lector, en la arena del periodismo dispuestos como el mejor torero, no a exterminar el primer bicho que parta sobre nosotros pero sí a sacar el cuerpo a la cornada que se nos dirija, venga de donde viniera e hincar de cuando en cuando alguna banderilla, si no lujosa, al menos oportuna y con limpieza. (El Barbero, 1892a, p. 1)

Al realizar una analogía entre una corrida de toros y el periodismo, deja claro el carácter combativo que se autoasignaba en el medio. El Barbero se entendía a sí mismo como un espacio, una arena de lucha, pero sobre todo como una especie de espectáculo público para debatir y emitir críticas. Sobre su posicionamiento para esto menciona que "en cuanto a bandera, no tenemos por ahora, sino el palo" (El Barbero, 1892a, p. 1). Así, hacen referencia a una supuesta imparcialidad que puede ponerse en duda al ir observando los objetivos de las caricaturas y sátiras textuales.

Otro periódico de relevancia fue El Mago (figura 7), también bogotano, que circuló entre el 1 de noviembre de 1891 y el 10 de abril de 1892. De periodicidad semanal, se imprimía en la imprenta de Torres. Su redactor era Juan Ignacio Gálvez y su grabador era José Ariosto Prieto, y se definía a sí mismo como de "crítica política". En el primer número se observa el siguiente texto que acompaña el título: "A todos y a ninguno, mis advertencias tocan, quien haga apreciaciones, con su pan se las coma" (El Mago, 1891).

Todos los números bajo este título constan de cuatro páginas y su texto se escribe a tres columnas. Presenta al menos una caricatura de significativo tamaño por edición, y esta se intercala con el texto. La técnica utilizada es el xilograbado. Algunas ediciones tienen una presentación mucho más ornamentada e ilustrada del nombre del periódico en comparación con otras en las que apenas aparece el nombre escrito. 


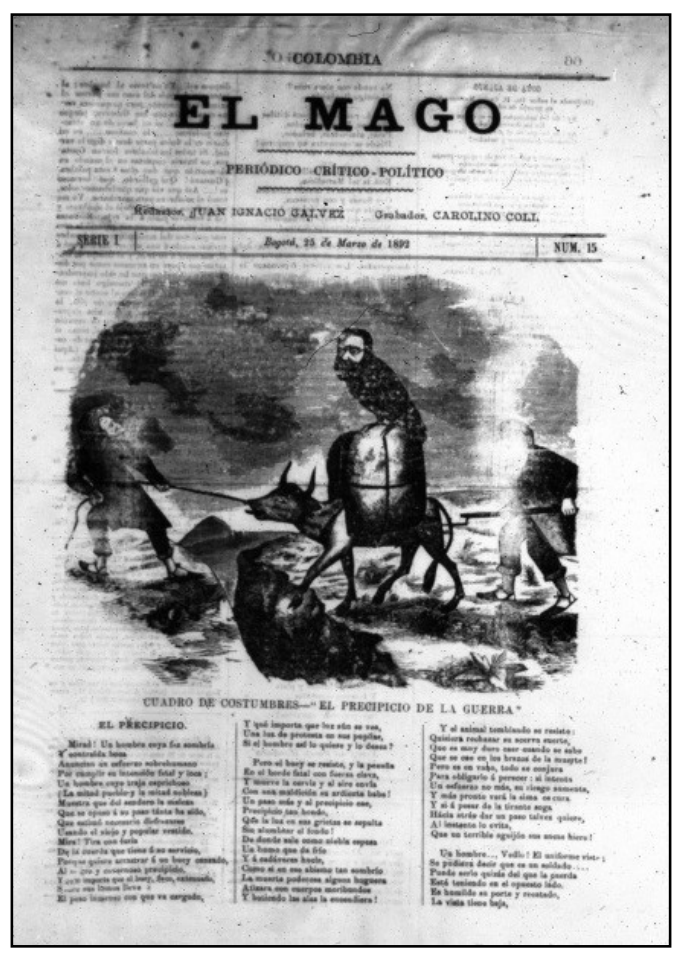

Figura 7. Portada de El Mago n. ${ }^{\circ} 15$

Fuente: El Mago (1892b).

En su presentación inaugural, El Mago (1891), en un breve texto editorial, afirma que "vamos a decir algo no sobre el por qué publicamos nuestra hoja, que eso lo dejamos a la libre consideración, sino sobre lo que puede el público encontrar en las columnas de El Mago" (p. 1). A continuación, menciona que su propósito era la publicación de un periódico político, pero al no tener gran aceptación en el público este género, descartó la opción. La idea de un periódico literario también fue barajada, pero no se consideró apropiada debido a que no sería económicamente sustentable. Una publicación exclusivamente satírica y burlesca, si bien es la opción a la que parece inclinarse más, no la acepta completamente por la supuesta falta de colaboradores. Por eso elige:

nuestro intento ha sido que El Mago pueda ser leído aún por aquellos que no saben, se nos hallará razón para haber reunido en él, como lo haremos, la política seria, la sátira y la poesía y adornarlo con caricaturas sociales. [...] Aprecien pues los políticos y los hombres serios nuestra hoja por lo que para ellos se escribe; la juventud alegre y bulliciosa que de todo ríe y de todo habla, por lo que de su agrado contiene; y aquellas almas bellas que venidas de la región de la poesía, no gustan sino de lo que les recuerda a su patria, aprécienla por lo que para ellas se hizo y quedarán satisfechos nuestros deseos. (El Mago, 1891, p. 1) 
En su presentación, la risa y el humor se colocan como protagonistas de las ediciones que serán publicadas a futuro.

Otra de los periódicos del género que tuvo notable trascendencia fue Mefistófeles. Semanario ilustrado de crítica social y política (figura 8), publicado en Bogotá entre el 23 de mayo de 1897 y el 28 de mayo 1899. Su director y propietario era Alfredo A. Borda y el grabador era Darío Gaitán. Salía a la luz semanalmente y en ocasiones tuvo dos ediciones en este mismo período. Los primeros números informan que se imprimía en la imprenta El Comercio, pero en otros momentos menciona la imprenta Mefistófeles o a la tipográfica El Globo. Generalmente, la publicación contaba con cuatro páginas, salvo los números donde son incluidos excepcionalmente varios avisos publicitarios que generan la necesidad de agregar más planas. Las partes textuales están siempre organizadas en tres columnas, y las imágenes se intercalan entre ellas gracias a la utilización de xilografía.

En su primer número, explica de dónde y por qué toma su nombre, además de referir su programa de la siguiente manera:

En la serenata de la ópera del Fausto, Mefistófeles es una carcajada homérica que de todo se burla. El mundo es una gran mascarada y el periódico Mefistófeles que de improviso se presenta en la escena será un pobre diablo vestido de colorado que estará en todas partes juguetón y burlón. Se reirá de los candidatos y de los políticos, sobre todo de los políticos de la granjería [sic]; de los periodistas y literatos cursis; de los poetas ramplones; de los militares de relumbrón; de las viejas entrometidas; de las jamonas que usan papelillo y de las muchachas coquetas [...]. Es claro que no puede haber ningún diablo conservador, aun cuando Lucifer tiene en los profundos muchos, muchísimos conservadores, y, por consiguiente, es claro que Mefistófeles será liberal, pero esto no obsta para que de cuando en cuando les arroje (ilegible) a los suyos un poquito de plomo caliente para que se compongan y no duerman tanto, que es defecto principal en los suyos dormir mucho [...]. Al que le caiga el guante que se plante. (Mefistófeles, 1897a, p. 2)

En este pequeño fragmento puede apreciarse, en primer lugar, que su objetivo es la burla y que uno de los escenarios principales donde la ejerce es el político. En segundo lugar, menciona a los "periodistas y literatos cursis", con lo que coincide, en este sentido, con las características del género comentadas en el apartado anterior. Por otro lado, define una postura política clara: será liberal, lo cual no le impedirá ser crítico con su sector político. Ante esto, menciona que también hará de los suyos con los políticos liberales con el objetivo de que se "compongan y no duerman tanto", de modo que podría leerse entre líneas la función que se asigna a sí misma la publicación: tener incidencia y cultivar cierto control moral y cívico a través de la burla y del humor. 


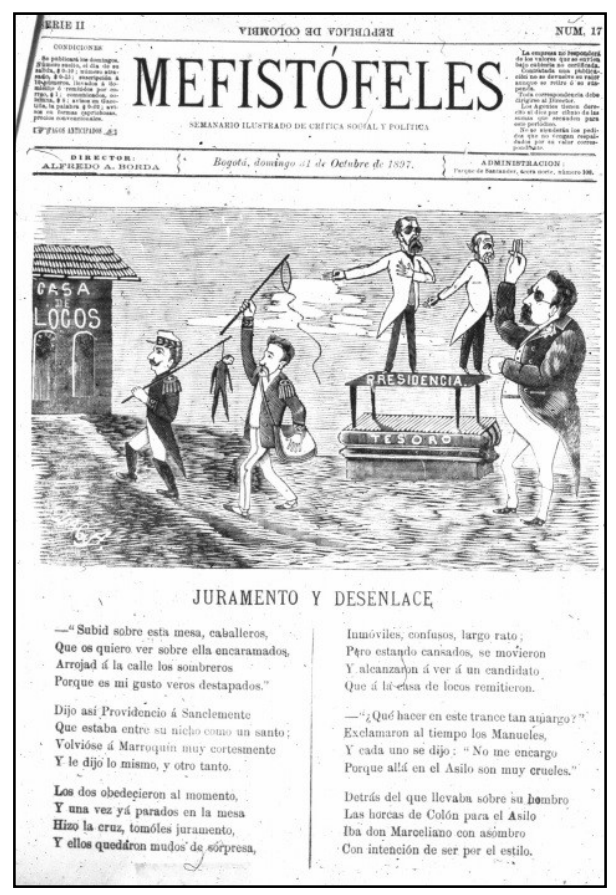

Figura 8. Portada de Mefistófeles $\mathrm{n} .^{\circ} 17$

Fuente: Mefistófeles (1897c)

También publica el siguiente párrafo en su número de inauguración bajo el título "Revista de la prensa":

La Época de Zuleta ha pasado porque murió de enfermedad microbiana, y como fue sepultada en los albañales está produciendo el tifus que hoy azota a esta ciudad. El Correo Nacional se enloda. Bogotá sufre toda infección. El Telegrama se achicó. El Progreso dicen que es la reelección. El Viajero dicen que está fatigado y por eso anda muy despacio. El Constitucional no lo es. El Nacionalista opera la destrucción y es personalista. El Orden se lo llevaron los diablos. La Crónica no falta. La Expectativa cansa. Fray Gerundio es Tirabeque y Pelegrín. La Tarde está oscura. El Siglo se acabará pronto. El Derecho no se perderá si vienen los radicales al poder. El Día muestra las cosas que no se ven en la noche, y es muy caluroso. El Tío Juan dio consejos a sus sobrinos y murió á edad no muy avanzada. El Rayo $X$ hace ver los objetos a través de los cuerpos y estudió las vías digestivas de $\mathrm{D}$. Chepe. La Mujer es decorosa y tímida como las violetas, pues no se ve. Luz del Hogar no alumbra porque hace falta. Cuba es enemiga del español. Mefistófeles ayudará a los Faustos y se reirá de muchos. (Mefistófeles, 1897a, p. 2)

Aquí se pasa revista, en el sentido de hacer una inspección o examen del estado del periodismo en la época en el cual nombra las publicaciones coexistentes y emite un juicio de valor al respecto de las mismas. De esta manera, y 
hacia el final del texto presentado, Mefistófeles se ubica a él mismo y a su misión dentro del estado en que se encuentran las publicaciones periódicas en 1897.

En suma, El Zancudo, El Barbero, El Mago y Mefistófeles fueron publicaciones de cierta relevancia dentro del género de la prensa satírica bogotana decimonónica que comparten aspectos similares con sus pares sudamericanos. Esto puede observarse en aspectos como el formato de cuatro páginas, la centralidad de la imagen, la estructuración del texto, las intenciones críticas, los nombres referentes a elementos molestos, engañosos, incisivos y cortantes. Sin embargo, otros elementos que serán explorados más adelante representarán ciertas singularidades de los periódicos publicados en la capital colombiana.

\section{La prensa satírica bogotana como fuente de estudio para la historia}

Como fue mencionado con anterioridad, las caricaturas políticas vehiculadas por la prensa satírica presentan un gran potencial de uso como fuente histórica. Estas interpretan la realidad y condensan críticas y opiniones sobre la coyuntura desde las posibilidades que las caracterizan. Por lo tanto, constituyen un corpus documental de gran relevancia para poder acceder a las percepciones sobre determinados procesos del pasado.

Esto puede ser observado en la breve selección de caricaturas que tienen como común denominador la representación en diversas situaciones en las que se coloca como protagonista a Miguel Antonio Caro (1843-1909). Al momento de ser publicadas estas caricaturas, este formaba parte del grupo que estaba en el poder y lideraba el proceso de regeneración en Colombia. Fue presidente entre 1892 y 1898. También se reconoce la presencia de Rafael Núñez (18251894), presidente en varias ocasiones durante las últimas décadas del siglo XIX, y de Carlos Holguín Mallarino (1832-1894), encargado de la presidencia entre 1888 y 1892. A estos tres personajes El Barbero (1891) los llama jocosamente "la Santísima Trinidad de la Regeneración".

Estas caricaturas representan a dichos personajes con el objetivo de emitir ciertos juicios de valor sobre los mismos y sus presuntas acciones. En la figura 9 se observa a Holguín y Núñez trasladando a Caro, en una crítica que se desarrolla en el texto de la publicación, en la cual postula que la Regeneración estaría tan ociosa en Colombia que se dedicaría a hacer este tipo de mudanzas infundadas. Caro, ubicado en el centro de la imagen, da instrucciones de forma autoritaria a los otros dos personajes que están subordinados a su voluntad. Esto también sugiere una vinculación entre Caro y una autoridad asociada a un régimen monárquico. 


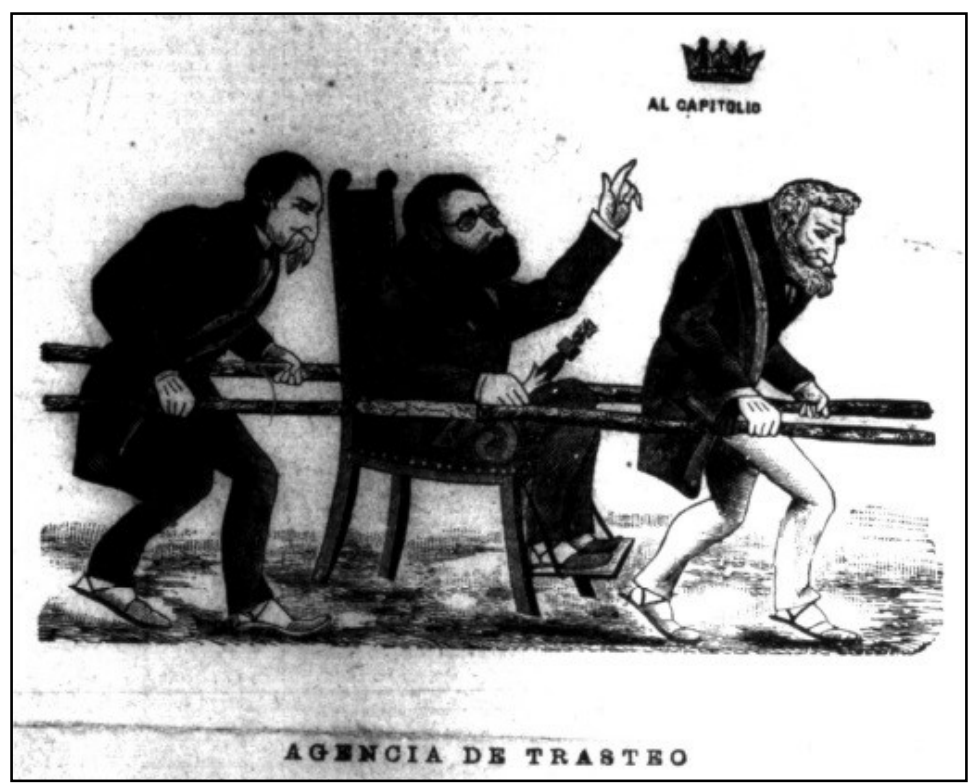

Figura 9. El Zancudo n. ${ }^{\circ} 43$

Fuente: El Zancudo (1791 [1891]).

Por su parte, la figura 10 expresa una idea similar. Tiene, asimismo, como centro a Caro en una situación de coronación. Pero, en vez de que se le coloque una corona tradicional, se le está colocando una coroza en su cabeza, definida como "distintivo prosaico y vergonzoso" (El Barbero, 1892 p. 1). Los coronadores son un grupo de tres hombres entre los que se encuentran nuevamente Holguín y Núñez. Probablemente esta imagen refiere a la posterior asunción del mando presidencial por parte de Caro en agosto de ese mismo año. Para este cargo había sido elegido Núñez, pero no lo pudo asumir por motivos de salud, por lo que Caro, electo vicepresidente, ocupó el puesto. La caricatura muestra un Rafael Núñez envejecido y no especialmente vital. El periódico describe esta situación de la siguiente manera:

el coronamiento de una especie de Cacique, después de cuatrocientos años de abolidos los caciques y los cacicazgos, y por encima de ochenta y dos años de eliminadas, pisoteadas y escarnecidas las coronas reales en esta malaventurada y peor aporreada Colombia. (El Barbero, 1892, p. 2)

Tanto la caricatura como el texto toman una postura de distanciamiento y antagonismo respecto a la situación representada y la asocian con valores con los cuales no se identifican. Estos son, por un lado, la idea del "cacicazgo" entendido en un sentido despectivo y asociada al mundo indígena, del cual, de forma general, las élites latinoamericanas buscan distanciarse en el siglo 
XIX por vincularse con la idea de "barbarie" opuesta a la "civilización" que querían alcanzar.

Por otro lado, se establece un vínculo con la monarquía española, otrora gobernante de ese territorio y rechazada por El Barbero, según sugiere. En un contexto de afirmación de una idea de república en Colombia, esto tiene una connotación especial, puesto que la monarquía es una figura de la cual se pretende marcar una discontinuidad para afirmar la consolidación del Estado que tiene la voluntad organizarse en moldes republicanos.

Este tipo de imágenes pueden pensarse a partir de uno de los elementos disponibles en el "arsenal del caricaturista": la condensación (Gombrich, 1998). La concentración y disposición de ciertos elementos en una caricatura como esta, comunican una idea que requiere poca explicación para ser razonada por sus contemporáneos, pues se entendería por sí misma. Esto sucede si el espectador posee los elementos de inteligibilidad ${ }^{6}$ necesarios de una época o de un lugar determinados para la decodificación.

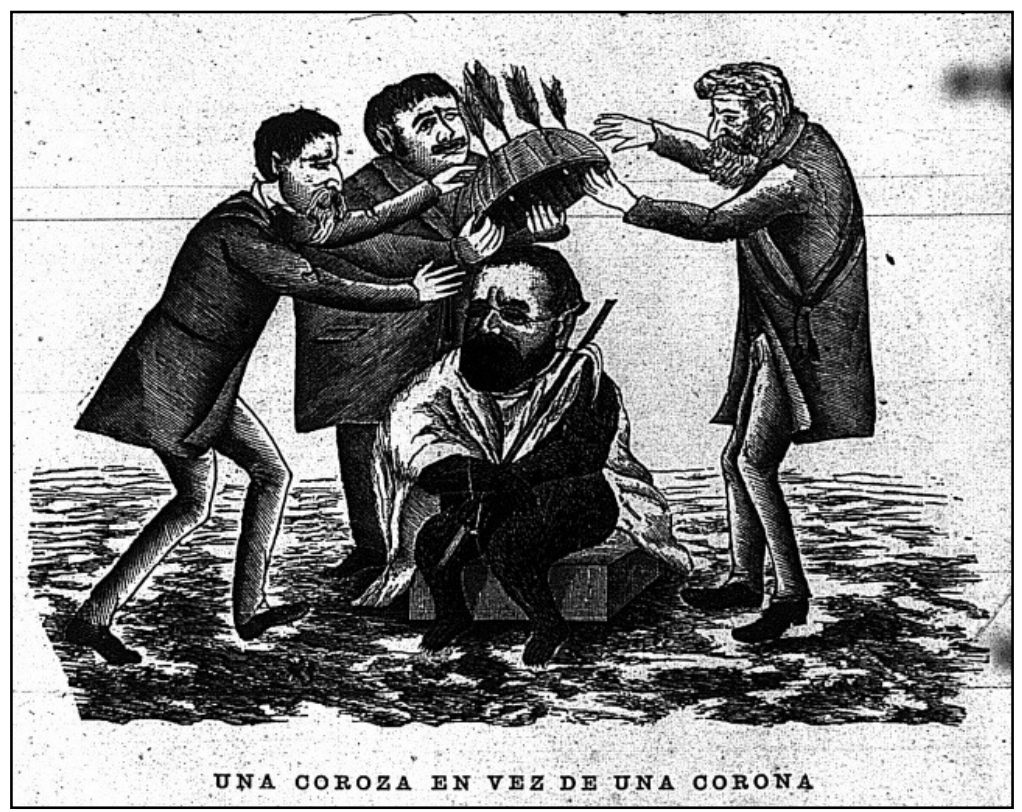

Figura 10. El Barbero n. ${ }^{\circ} 1$

Fuente: El Barbero (1892a).

El Mago, por su parte, también vincula a Caro, Holguín y Núñez en el marco de la contienda presidencial que estaría disputándose en 1892 (figura 11). En una

\footnotetext{
6 En este caso, se trata de reconocer los sujetos y su vinculación, la expresión de jerarquía, entre otros elementos. 
especie de "busto-vasija" con la cara de Holguín, Núñez introduce un personaje vestido con uniforme militar. En la secuencia, este sale con ropas circenses y puede observase que se trata de Caro, a quien el propio Núñez está esperando fuera de la boca de Holguín-vasija. Podría interpretarse que esta imagen refiere a la "fabricación" de un candidato para que acompañe a Núñez en la contienda presidencial y que sea capaz de suceder la presidencia de Holguín, siguiendo las pautas por él marcadas. La caricatura apunta a la "invención" de este sujeto y al modelamiento por parte de quienes ya habían sido presidentes hasta entonces. Se muestra así una relación jerárquica entre los tres políticos, en la cual Caro se encuentra en el escaño inferior como el producto formado de lo que los otros quieren y esperan de él mismo.

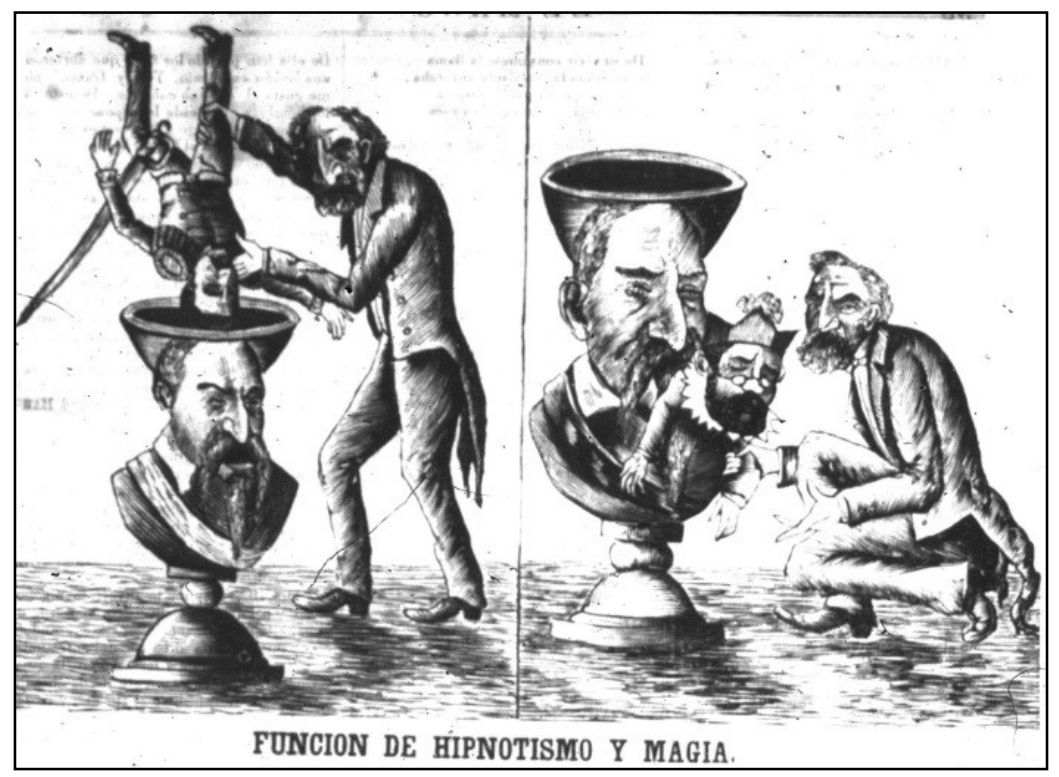

Figura 11. El Mago n. ${ }^{\circ} 14$

Fuente: El Mago (1892a).

Esta imagen recurre a otro elemento disponible para los caricaturistas, que es el retrato (Gombrich, 1998). Pero no es uno de tipo académico, realista y solemne, sino que es retrato sometido a las deformaciones/formaciones de la caricatura. El dibujante reconoce y plasma los rasgos fisionómicos de un determinado sujeto en elementos inanimados como una vasija, pero que se reconocen con las características de alguien en particular. Matallana (2010) explica esto como el juego estético propio de la caricatura que se aleja de su referente, pero no a una gran distancia, puesto que siempre es necesaria la inclusión de ciertos rasgos para su identificación. 
Haciendo un salto hacia los finales del mandato de Miguel Antonio Caro, la figura 12 utiliza un escenario circense para la representación de una situación política que parece estar en discusión al momento de ser publicado el número 5 de Mefistófeles.

Cabe destacar, en primer lugar, el espacio de la arena donde se desarrollan espectáculos. En páginas anteriores fue mencionada la idea de que los periódicos se entendían a sí mismos como lugares de combate y examen político. Aquí se observa de forma directa esta relación: la página se convierte en una arena circense para desplegar la idea de una acción política.

La caricatura hace referencia a una posible reelección en el cargo de presidente por parte de Caro, lo cual se entiende como un camino marcado por la inestabilidad. El gobernante es representado como un equilibrista en una cuerda que lo conduce directamente a la reelección. El camino que debe atravesar presenta el obstáculo de un gran nudo que puede hacerlo caer, pero que hasta el momento no lo ha hecho.

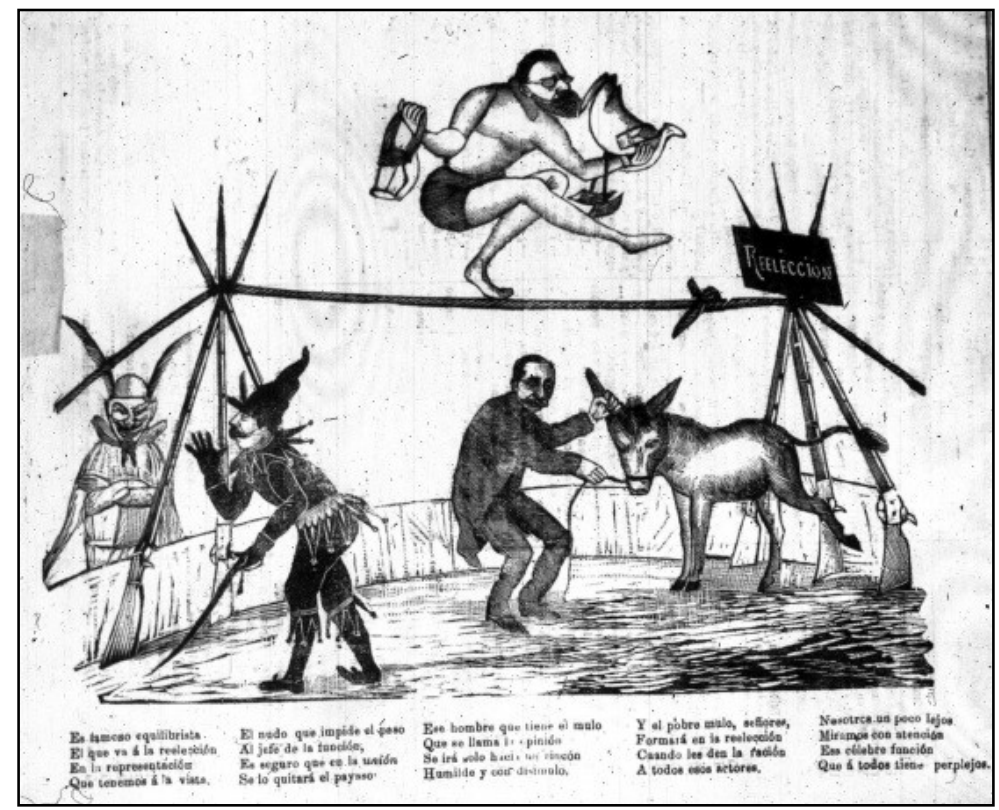

Figura 12. Mefistófeles n. ${ }^{\circ} 5^{7}$

Fuente: Mefistófeles (1897b).

Al pie de la caricatura puede leerse "El famoso equilibrista, Él que va a la reelección, En la representación, Que tenemos a la vista. / El nudo que impide el paso, Al jefe de la función, Es seguro que en la unión, Se lo quitará el payaso. / Ese hombre que tiene el mulo, Que se llama la opinión, Se irá solo hacia un rincón, Humilde y con disimulo. / Y el pobre mulo señores, Formará en la reelección, Cuando les den la facción, A todos esos actores. / Nosotros un poco lejos, Miramos con atención, Esa célebre función, Que a todos tiene perplejos. 
La imagen evidencia un aspecto particular del trabajo con fuentes de publicación periódica que acompañan la cotidianeidad de las personas. Efectivamente, Caro no fue a la reelección por ser inhabilitado, y en su lugar decidió darle su apoyo a Manuel Antonio Sanclemente como candidato a la presidencia y a José Manuel Marroquín en la vicepresidencia, quienes salieron victoriosos en 1898. Los editores y caricaturistas de Mefistófeles no tenían cómo saber esta información para 1897, donde la nueva candidatura de Caro era algo todavía posible. En este sentido, las caricaturas de la prensa periódica permiten conocer el desarrollo de los acontecimientos desde la indeterminación y sin conocimiento del final del proceso; apuntan a los temores, expectativas e incertidumbres del cotidiano de las sociedades en que se enmarcaban. Estas imágenes, en conjugación con los textos con los que comparten el papel, son una herramienta para acceder a las formas de concebir los procesos históricos, sociales, políticos y culturales desde la cobertura cotidiana que posibilitan estas publicaciones. Así, puede entenderse que "el humorista político ejerció una función de cronista de la época" (Matallana, 2010, p. 17).

En suma, estas y otras imágenes de este tipo circularon en Bogotá a finales del siglo XIX y construyeron un imaginario particular sobre el panorama político del momento, los sujetos protagonistas y las situaciones en que se enmarcaban, desde una particular carga ideológica. Cada una de las publicaciones que las contienen "responde a la pregunta por la identidad: '¿Quiénes somos?' y define, en consecuencia, a través de sus críticas, otro" (Matallana, 2010, p. 18). Se considera que la adhesión o el rechazo sobre los discursos contenidos en estas imágenes genera un sentimiento de identidad o alteridad en ciertos grupos sociales que los aproxima o distancia de los mensajes transmitidos.

Al dar cuenta de imaginarios políticos, consolidan sentimientos identitarios que se vinculan con formas de concebir el Estado nacional en su momento y con proyectos políticos particulares de país en la época. En este sentido, las caricaturas políticas colombianas presentadas inciden en el proceso de configuración del Estado desde una perspectiva simbólica y tienen injerencia en la forma que generan opiniones al respecto de los acontecimientos. La contribución no solo está dada por su colaboración con la formación de opinión pública, sino también por la forma en que ponen en circulación imágenes y textos que refieren a ese proceso. En una época en la cual la circulación de artefactos visuales no era tan alta como en la contemporaneidad, estos periódicos contribuyeron a la socialización de representaciones visuales de representantes de la política y del Estado. 


\section{Particularidades del caso bogotano}

Ya esbozadas las características principales del género de la prensa satírica a nivel sudamericano y presentados algunos títulos de este tipo de publicaciones en Bogotá, se pueden vislumbrar algunas de las particularidades que presenta el fenómeno en la capital colombiana. Entre ellas se destacan el protagonismo del uso del xilograbado sobre la litografía y la fuerte presencia de la censura que condiciona las formas de comunicación.

Tanto El Zancudo como El Barbero y El Mago dedican un espacio del periódico a la publicación del texto del Decreto 151 (1888), el cual se presenta por fragmentos a lo largo de varios números. Este decreto entiende a la prensa como un instrumento pasible de ser usado en contra del Estado y, por tanto, busca desestimular los posibles abusos los periódicos que podrían ejercer.

En el texto del Decreto 151 (1888) se enumeran los considerados delitos de las publicaciones periódicas contra la sociedad entre los cuales se pueden encontrar "atacar a la religión católica" (art. 4, n. 2), "atacar la institución militar" (art. 4, n. 4), "ofender la decencia pública con escritos obscenos o noticias escandalosas" (art. 4, n. 1) y también condena posibles embestidas contra las leyes o instituciones (art. 4, n. 1 ).

Por su parte, Mefistófeles dedica un espacio a la publicación de legislación de prensa refiriendo a la Ley 157 (1896) que tenía el objetivo de regularla. Además de disponer lo que se consideraba como un crimen de prensa en similitud con lo que estipulaba el Decreto 155, esta ley exigía que:

Todos los propietarios, administradores o encargados de imprentas en el territorio de la República, tienen el deber, dentro de los sesenta días subsiguientes a la promulgación de esta ley, de informar al Gobernador del Departamento respectivo y al Ministro de Gobierno, por medio de manifestación escrita en papel sellado, acerca de lo siguiente: $1^{\circ}$ Nombre del lugar donde se halle el establecimiento; $2^{\circ}$ Nombre de la imprenta; y $3^{\circ}$ Nombre y nacionalidad de su propietario. (Ley 157, 1896, art. 6)

Además, el numeral 1 del artículo 10 prohibía la utilización de pseudónimos o producciones anónimas. Por ello, sumado a lo anterior, se observa una fuerte intención de identificación de los responsables de las publicaciones.

En el número 1 de Mefistófeles, se transmite una carta de su director Alfredo Borda dirigida a el ministro de Gobierno Antonio Roldán, en la cual solicita: "por si fuere posible considéreseme, permiso para suplir mi nombre con un pseudónimo cosa que no es contraria al espíritu de la ley ya citada, porque yo, como director y propietario del periódico, responderé ante el Gobierno" (Mefistófeles, 1897a, p. 2). La respuesta de Roldán es colocada a continuación: "no está permitido sustituir el nombre del director responsable del periódico por ningún otro, 
porque la ley es clara a este respecto y no es el caso de consultar su espíritu" (Mefistófeles, 1897a, p. 2).

Esto se explica porque todos estos periódicos se enmarcan dentro del período conocido como la Regeneración, donde el Estado controló fuertemente ciertos aspectos de la esfera pública. En esta época — también llamada de hegemonía conservadora-, la Iglesia católica cobró un lugar protagónico siendo parámetro único de la moral y los valores que debían imprimirse en la sociedad.

Durante la Regeneración se ejerció particularmente un potente control sobre la prensa, como se puede apreciar en la ley y decreto anteriormente citados que influenciaron la forma que tomaron los medios de comunicación impresos. Los periódicos aquí indicados son opuestos a las políticas creadas en esta época, pero tuvieron que jugar en el marco de la legalidad establecida y colocar sus permisos de circulación y vocería como cartas de acreditación ante el público.

Sin embargo, el propio espíritu de la prensa satírica los lleva a jugar en el límite de lo legal, lo que hace que la mayoría de estos emprendimientos de publicación acaben siendo cerrados por expresa indicación del Gobierno. El Zancudo y El Barbero, los periódicos de Greñas, están dentro de estos casos, por lo que su propietario y creador de los proyectos fue condenado al destierro. A raíz de esto, Greñas se instala en Costa Rica, donde también se dedica a la producción de impresos, convirtiéndose en una referencia local en el área.

$\mathrm{Al}$ respecto de la censura, la portada del número de 5 de El Barbudo exhibe la siguiente imagen (figura 13):

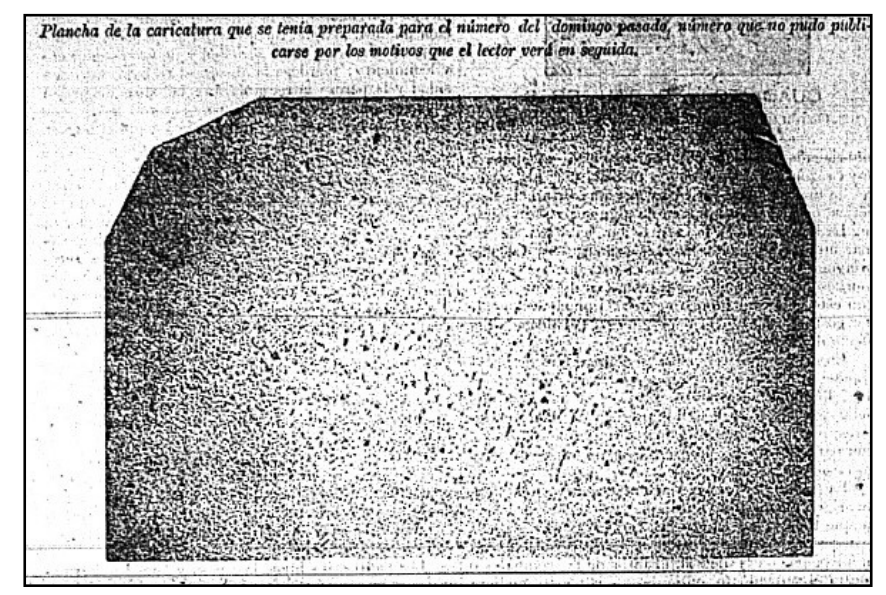

Figura 13. Plancha de la caricatura que se tenía preparada para el número del domingo pasado, número que no pudo publicarse por los motivos que el lector verá en seguida

Fuente: El Barbudo (1892, p. 1). 
Se informa que, por orden de la Secretaría de Gobierno, se les habría prohibido la publicación de una caricatura de Carlos Holguín quien ejercía su función de presidente en ese momento. Ante esto, se redacta la siguiente queja:

No existe, entre las disposiciones sobre prensa de suyo restrictivas que hoy nos rigen, ninguna que autorice la resolución del señor Secretario de Gobierno; es éste un nuevo atentado que comete la Regeneración contra la libertad de prensa, pasando sobre las propias restrictivas leyes que ella misma ha dictado. (El Barbero, 1892, p. 1)

El Barbero podría no haber publicado nada y omitir comentarios de la sanción. En cambio, decide publicar intencionalmente la imagen de la plancha sin caricatura junto a un comentario crítico sobre esto. Así, queda en evidencia la actitud limitante del ejercicio periodístico por parte del Gobierno, y la imagen aparentemente "vacía" constituye una potente representación de la propia censura que este ejerce. Esto se hace, aparentemente, sin violar la norma establecida, pero jugando al límite de la misma.

A partir de este número 5, El Barbero cambia radicalmente las directrices sobre las imágenes que vehicularía el periódico. Se publican en los números sucesivos imágenes de tipo artísticas y láminas con temas costumbristas y de humor. Estas figuras jocosas, no obstante, no se realizan con la tónica que se hizo en los primeros números ni "atacando" a los políticos de turno.

La otra particularidad observada en la prensa satírica bogotana de finales del siglo XIX es el protagonismo del xilograbado para la reproducción de imágenes, a pesar de que la tendencia regional en esta época era la utilización de la técnica litográfica para dichos fines. Si bien la litografía estaba presente en Colombia desde la década de los años veinte y fue utilizada para la publicación de algunos periódicos, como Los Matachines ilustrados (1855) o El Alcanfor (1878 -1880), al final del siglo se observa una mayor utilización del grabado en madera, utilizado en los cuatro periódicos analizados en este artículo en contraposición a lo que ocurre en otros países de la región (figura 14).

Probablemente, esto se deba a la gran influencia de Alberto Urdaneta (18451887), artista colombiano de enorme importancia en el medio periodístico finisecular. Fue fundador del periódico con caricaturas El Mochuelo (1877), pero su gran reconocimiento fue por Papel Periódico Ilustrado (1881-1888), publicación de referencia en el medio colombiano de la época que fue vehículo de columnas y grabados sobre la cultura, las artes y la historia, y que procuraba conformar un corpus visual que con el tiempo se constituyera como un "álbum nacional" (Pérez, 2015). Esta publicación se entendía también como la materialización de innovaciones tecnológicas. En este sentido, Solano (2011) apunta: 
El Papel Periódico Ilustrado hacía parte de la inmensa minoría de publicaciones periódicas dedicadas a la divulgación de la cultura en Colombia durante el siglo XIX, ya que el $90 \%$ de la producción estaba dirigida al combate político y a la divulgación ideológica. (p. 148)

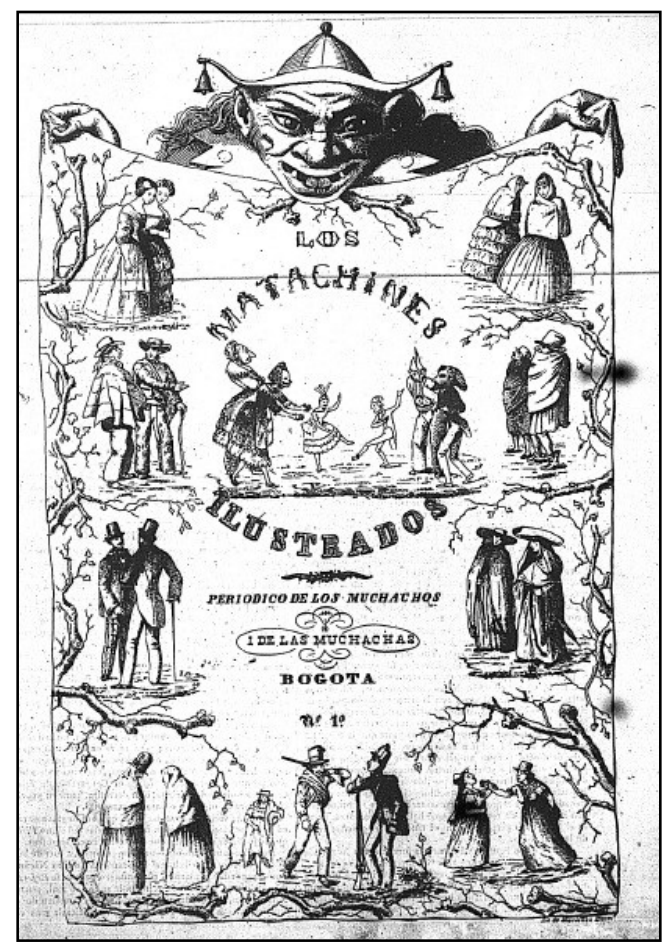

Figura 14. Portada de Los Matachines Ilustrados n. ${ }^{\circ} 1$

Fuente: Los Matachines Ilustrados (1855).

Para su realización, Urdaneta invitó a Antonio Rodríguez, grabador español que vivía en París, para trabajar en Bogotá dentro de Papel Periódico Ilustrado y para colaborar con la escuela de grabado impulsada por él mismo. En esta escuela aprendieron el oficio alumnos como Greñas, quien volcó sus conocimientos en El Zancudo y El Barbero posteriormente.

La xilografía de pie o a fibra, impulsada en Colombia por Urdaneta, utilizaba

las planchas de madera de árbol de Boj. Este tiene unas características especiales pues por una parte ofrece dureza suficiente para resistir la presión de la prensa

8 Si bien la publicación no era combativa en términos políticos como los periódicos satíricos que se han analizado en este artículo, esto no quiere decir que no tenga un posicionamiento ideológico. Amada Carolina Pérez (2015) menciona que si bien Papel Periódico Ilustrado quería mostrarse imparcial, se inclinaba a apoya el proyecto político de alianza entre liberales moderados y conservadores: la Regeneración. 
de imprimir, y, por otra parte, posee una cierta blandura que posibilita los trazos del buril. (Solano, 2011, p. 149).

La difusión de esta técnica en Colombia por las enseñanzas e influencia de Urdaneta y la trascendencia de Papel Periódico Ilustrado (figura 15), hizo que la tecnología de reproducción preferida en las publicaciones ilustradas de finales de siglo haya sido la xilografía en desmedro de la litografía.

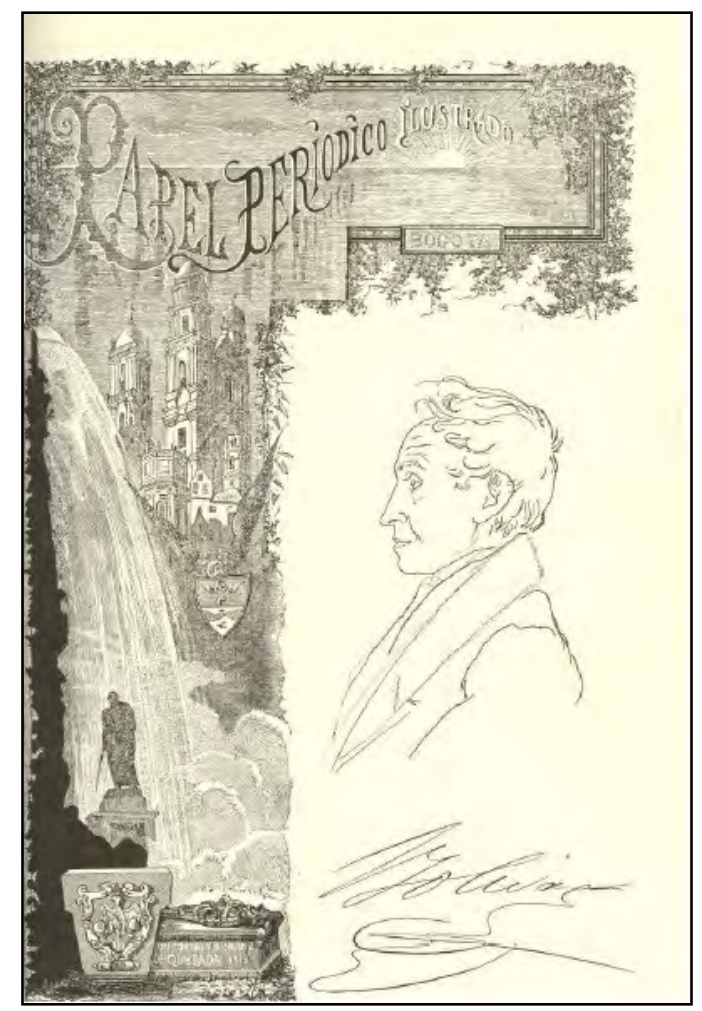

Imagen 15. Portada de Papel Periódico Ilustrado n. ${ }^{\circ} 1$

Fuente: Papel Periódico Ilustrado (1881).

\section{Consideraciones finales}

En resumen, este trabajo buscó, en un primer momento, mostrar un panorama regional de la prensa satírica en Sudamérica a partir de la contextualización de su surgimiento y auge de circulación en la mitad del siglo XIX. En segundo lugar, procuró esbozar un breve panorama de cómo se desarrolló el fenómeno en el caso bogotano en las últimas décadas del siglo, apuntando a las particularidades observables a partir del análisis de los periódicos seleccionados por su destaque en el medio. 
La finalidad de fondo del artículo ha sido poner en valor un corpus documental que, sin duda, necesita ser mucho más explotado e investigado para aprovechar sus potencialidades como fuente para el estudio del pasado. Por otro lado, el camino escogido para llegar dicho objetivo a partir de la reflexión del fenómeno a nivel sudamericano, también se considera un recorrido interesante para reterritorializar objetos de estudio y pensar la historia desde nuevas perspectivas espaciales.

A partir de este "camino de razonamiento" se puede afirmar que la prensa satírica bogotana presenta características que la ubican dentro del fenómeno a nivel regional y que posibilitan pensarla en este contexto. No obstante, las condiciones especiales presentes en Colombia a finales del siglo XIX, en relación con la difusión de una técnica y la legalidad de los impresos, moldearon particularmente las publicaciones dándole rasgos puramente locales.

\section{Agradecimientos}

Agradezco a la profesora dra. Amada Carolina Pérez por las orientaciones recibidas durante mi estancia de investigación en la Pontificia Universidad Javeriana de Bogotá a finales de 2019, que fueron de gran inspiración y ayuda para la redacción de este artículo de reflexión.

Expreso mi gratitud también a la Agencia Nacional de Investigación y Desarrollo de Chile (ex Conicyt) que, a través de la Beca de Doctorado Nacional 2018 concedida, permitió desarrollar este artículo en el marco de la investigación doctoral en curso titulada Guerra, nación e imagen. La prensa satírica durante la guerra de la Triple Alianza y la guerra del Pacífico (1864-1883) dentro del doctorado en Historia de la Universidad de Santiago de Chile.

\section{Referencias}

Acevedo, D. (2003). La caricatura editorial como fuente para la investigación de la historia de los imaginarios políticos: reflexiones metodológicas. Historia y Sociedad, 9, 151-173. https://revistas.unal. edu.co/index.php/hisysoc/article/view/23222

Anderson, B. (1993). Comunidades imaginadas. Reflexiones sobre el origen y difusión del nacionalismo. Fondo de Cultura Económica.

Beretta García, E. (2012). La litografía, la difusión de la imagen y su papel como herramienta propagandística en Montevideo durante el siglo XIX. Cuadernos de Historia, 17-38. http://bibliotecadigital. bibna.gub.uy:8080/jspui/handle/123456789/50877

Beretta García, E. (2016). Dibujos y acuarelas, estampas y prensa. Los artistas como reporteros gráficos y publicistas en Montevideo (1830 - 1851). Revista Claves, 3, 45-71. https://ojs.fhce.edu.uy/ index.php/claves/article/view/393 
Burkat, M. (2007). La prensa de humor político en Argentina: de "El Mosquito" a "Tía Vicenta." Questión, 1(15). https://perio.unlp.edu.ar/ojs/index.php/question/article/view/420

Cornejo, T. (2019). Ciudad de voces impresas. Historia cultural de Santiago, 1880-1910. Ediciones Biblioteca Nacional de Chile.

Cabuchuí (1867, 16 de mayo). Portada. Cabuchuí (2). http://bibliotecanacional.gov.py/hemeroteca/ coleccion-cabichui-del-n-1-al-n-55/

Caras y Caretas (1900, 26 de mayo). Portada. Caras y Caretas (86). http://hemerotecadigital.bne.es/ results.vm?q=parent\%3A0004080157\&s $=80 \&$ lang $=\mathrm{es}$

Charivari, El. (1867, 29 de junio). Portada. (1).

Charivari Bogotano, El (1848, 1 de octubre). Portada. (1). http://babel.banrepcultural.org/digital/collection/p17054coll26/id/1391

Costa, M. E. (2009). De la imprenta al lector. Reseña histórica de la edición de libros y publicaciones periódicas en Buenos Aires (1810 - 1900). Questión, 1(23). https://perio.unlp.edu.ar/ojs/index.php/ question/article/view/822

Cuarterolo, A. (2017). Entre caras y caretas: caricatura y fotografía en los inicios de la prensa ilustrada argentina. Significação, 44(47), 155-177. http://www.revistas.usp.br/significacao/article/view/127322

El Barbero (1791, 8 de septiembre). Sin título. El Barbero (43).

El Barbero (1892a, 27 de marzo). Portada. El Barbero (1).

El Barbero (1892b, 14 de abril). Portada. El Barbero (4).

El Barbudo (1892, 24 de abril). Sin título. El Barbudo (5).

El Mago (1891, 1 de noviembre). Editorial. El Mago (2).

El Mago (1892a, 13 de marzo). Función de hipnotismo y magia. El Mago (14).

El Mago (1892b, 25 de marzo). Portada. El Mago (15).

El Mosquito (1882, 19 de febrero). Portada. El Mosquito (998).

El Zancudo (1791, 11 de octubre). Portada. El Zancudo (49). https://catalogoenlinea.bibliotecanacional. gov.co/client/es_ES/search/asset/132605.

El Zancudo (1790, 22 de marzo). "El Zancudo". El Zancudo (1). https://catalogoenlinea.bibliotecanacional.gov.co/client/es_ES/search/asset/132591

Gantús, F. (2012). Caricatura y prensa, una reflexión en torno a las imágenes y su importancia en la investigación histórica. El caso mexicano, siglos XIX-XX. Domínios Da Imagem, 10, 73-88.

Gionco, P. (2016). De arenas, escenas y otras cuestiones públicas. Espectáculos y convergencia cultural en las páginas de El Mosquito. In Ilustrar e imprimir. Una historia de la cultura gráfica en Buenos Aires, 1830 - 1930 (pp. 87-112). Ampersand.

Gombrich, E. (1998). El arsenal del caricaturista. In Meditaciones sobre un caballo de juguete y otros ensayos sobre teoría del arte (pp. 127-142). Debate.

González, B. (2009). La caricatura en Colombia a partir de la Independencia. Banco de la República. 
La Ortiga y el Garrote (1874, 6 de diciembre). Portada. La Ortiga y el Garrote (53). https://anaforas.fic. edu.uy/jspui/handle/123456789/3948

Levín, F. (2015). Humor gráfico: manual de uso para la historia. Ediciones UNGS.

Los Matachines Ilustrados (1855, 6 de febrero). Portada. Los Matachines Ilustrados (1).

Matallana, A. (2010). Imágenes y representación. Ensayos desde la historia argentina. Aurelia Rivera.

Mefistófeles (1897a, 23 de mayo). Revista de la prensa. Mefistófeles (1).

Mefistófeles (1897b, 20 de junio). Sin título. Mefistófeles (5).

Mefistófeles (1897c, 31 de octubre).Portada. Mefistófeles (17).

Ministerio de Justicia (1888, 17 de febrero). Decreto 151 de 1888. Sobre prensa. Diario Oficial n. 7299. http://www.suin-juriscol.gov.co/viewDocument.asp?id=1034185

Ministerio de Justicia (1897, 12 de diciembre). Ley 157 de 1896. Disposiciones preliminares sobre prensa. Diario Oficial n. ${ }^{\circ}$ 10233. http://www.suin-juriscol.gov.co/viewDocument.asp?id=1793365

O Mosquito (1872, 6 de enero) Portada. http://bndigital.bn.br/acervo-digital/mosquito/709654

Papel Periódico Ilustrado (1881, 6 de agosto). Portada. Papel Periódico Ilustrado (1). http://babel.banrepcultural.org/cdm/ref/collection/p17054coll26/id/410

Pérez, A. C. (2015). Nosotros y los Otros. Las representaciones de la nación y sus habitantes. Colombia 1880-1910. Editorial Pontificia Universidad Javeriana.

Rojas Mix, M. (2009). El “98”. Las caricaturas y la guerra hispano-cubana de 1898. http://miguelrojasmix. com/el-98-las-caricaturas-yla-guerra-hispano-cubana-de-1898/

Román, C. (2010). La prensa satírica argentina del siglo XIX: palabras e imágenes. Universidad de Buenos Aires.

Solano, J. (2011). El grabado en Papel Periódico Ilustrado. Su función como ilustración y la relación con la fotografía. Revista de Estudios Sociales, 39, 146-156. https://revistas.uniandes.edu.co/doi/ abs/10.7440/res39.2011.12

Szir, S. (2009). De la cultura impresa a la cultura de lo visible. Las publicaciones periódicas ilustradas en Buenos Aires en el siglo XIX. En Imágenes, textos y contextos, colección Investigaciones de la Biblioteca Nacional. Teseo.

Szir, S. (2010). Romanticismo y cultura de la imagen en los primeros periódicos ilustrados en Buenos Aires: El Museo Americano. Estudios. Revista de Investigaciones Literarias y Culturales, 18(36), 296322. https://biblat.unam.mx/hevila/EstudiosRevistadeinvestigacionesliterariasyculturales/2010/ vol18/no36/3.pdf

Szir, S. (coord.) (2016). Ilustrar e imprimir. Una historia de la cultura gráfica en Buenos Aires, 1830-1930. Buenos Aires: Ampersand.

Szir, S. (2017). Imágenes y tecnologías entre Europa y la Argentina. Migraciones y apropiaciones de la prensa en el siglo XIX. Nuevo Mundo Mundos Nuevos. https://journals.openedition.org/nuevomundo/70851

Vasco, B. (2011). Periodismo político. La prensa bogotana en el siglo XIX. Alcaldía Mayor de Bogotá. 